\title{
Beyond entrepreneurship education: business incubation and entrepreneurial capabilities
}

Kenechukwu Ikebuaku and Mulugeta Dinbabo

\begin{abstract}
Purpose - As a way of dealing with Nigeria's macroeconomic challenge of unemployment and its concomitant socio-economic problems, the federal government, in 2006, made entrepreneurship study a compulsory course for all higher education students irrespective of their area of specialization. However, studies have shown that the programme is yet to achieve its goals as many Nigerian graduates still remain unemployed long after graduation. Using Sen's capability approach, this paper aims to investigate business incubation as an effective tool for enhancing entrepreneurial capabilities beyond entrepreneurship education.

Design/methodology/approach - This study has engaged both quantitative (survey questionnaire) and qualitative methodologies (semi-structured interview).

Findings - The result shows that through business incubation, budding entrepreneurs have increased access to infrastructures and resources necessary for entrepreneurial success, thereby enhancing their real opportunities (capabilities) for success.

Practical implications - For greater effectiveness, business incubation should be integrated into the current entrepreneurship education programme in Nigeria.

Originality/value - This study is a debut of research endeavours which theoretically assess entrepreneurship programmes via the capability approach lens. It has developed a conceptual model for assessing business incubation using the capability approach.
\end{abstract}

\section{Introduction}

Entrepreneurship has long been offered as the panacea for poor economic growth and high rate of unemployment (Matlay, 2008). This is especially true in developing countries grappling with heavy weights of high unemployment and poverty. In many African countries, the rate of population growth oversteps employment growth, necessitating the need to promote entrepreneurship as a means of creating employment and alleviating poverty (Okafor et al., 2015). However, the quest for enhancing entrepreneurial culture is a global endeavour. This explains the recent focus by governments and other stakeholders in various countries worldwide, on boosting entrepreneurial activities through investment in entrepreneurship education (European Commission, 2003; Harry Matlay et al., 2013). A major assumption in these developments is that entrepreneurship education increases students' career prospects and employability, either through enabling them to become selfemployed persons or through increasing their potential value as more enterprising 
employees (Rae and Woodier-Harris, 2013). Consequently, lots of efforts are being put into advancement of entrepreneurship education in formal school curriculum (Chimucheka, 2014).

Nigeria is not left behind in this move as its government has been implementing programmes to boost the entrepreneurial activities in the country. In 2006, the Nigerian Federal Government made entrepreneurship study compulsory for students of all higher education institutions (HEIs) irrespective of their areas of specialization (Nwekeaku, 2013). This mandate was seen as a potent weapon for dealing with the country's macroeconomic challenge of unemployment and its concomitant social and economic problems. However, as Aja-Okorie and Adali (2013) observed, despite the compulsory entrepreneurship education in HEIs, many Nigerian graduates still remain unemployed long after their graduation. Therefore, it appears that the entrepreneurship education delivered to undergraduate students is failing in meeting the set objectives, and the purpose of the programme appears to have been defeated (Aja-Okorie and Adali, 2013).

The thrust of this paper is that if entrepreneurship education is to yield the desired fruits of boosting entrepreneurial activities, there is need for a more comprehensive approach. The paper seeks to explore business incubation as a more effective tool for boosting entrepreneurial success beyond entrepreneurship education. Using Sen's capability approach, this study answers the following question: How have Information Technology Developers Entrepreneurship Accelerator (iDEA) Nigeria's programmes contributed to the enhancement of its participants' entrepreneurial capabilities? Considering the paucity of studies which have so far engaged the capability approach in assessing business incubation, the study provides a new lens for assessing the contribution of business incubators and other entrepreneurship programmes in the drive to enhance entrepreneurial activities and socio-economic development. The study adds value to policymakers in that it provides understanding on comprehensive approach to entrepreneurship development. For scholars, it is hoped that the study will stimulate further research on entrepreneurship using the capability approach.

The next section provides a background on the entrepreneurship education in Nigeria followed by a description of the methodology used. Literature review and theoretical framework of the study are also provided. Moreover, results and analysis of empirical findings regarding the entrepreneurship education, business incubation and expansion of entrepreneurial capabilities are discussed. Finally, suggestions and recommendations are provided.

\section{Background/contextualization}

The role of entrepreneurship in fostering economic growth and development has generated a strong interest among policymakers in recent years (Naudé, 2011). Even among scholars, entrepreneurship is seen as pivotal to economic growth in both developing and developed countries (Arokiasamy, 2012; Bakar et al., 2015; Carree and Thurik, 2010; Inyang and Enuoh, 2009; Lee et al., 2005; Ligthelm, 2008; Mitra et al., 2011). However, scholars like Sautet (2013) 
argued that the positive impact of entrepreneurship on economic development is only evident in developed economies, whereas no impact has been observed in developing countries. Throwing more light on the reason for this discrepancy, Acs (2006) noted that it is because of the differences in the types of entrepreneurship prevalent in different countries. While necessity entrepreneurship has no effect on economic development, opportunity entrepreneurship has significant positive effect. This position is corroborated by Edoho (2016) who observed that opportunity entrepreneurship boosts economic growth, creates jobs and helps in poverty alleviation. According to Global Entrepreneurship Monitor (GEM) (2008), necessity entrepreneurship is more prevalent in developing countries than in developed countries (2008, pp. 23-24). Nonetheless, it is generally agreed that, through its innovation, employment and welfare effects, entrepreneurship can serve as a powerful mechanism for driving development and boosting prosperity (Acs et al., 2008; Edmond et al., 2014). It contributes significantly to the development of small- and medium-scale enterprises which serve as the driving force of economic growth and development (Okafor et al., 2015).

Like many other developing countries, Nigeria has embraced entrepreneurship as a vehicle for employment creation and poverty alleviation (Okafor et al., 2015). This quest is of crucial importance, considering the alarming rate of unemployment, especially among the youth. According to Ukpong (2013), millions of Nigerian graduates are churned out by universities on a yearly basis with most of them having no hope of getting employment. Youth unemployment in Nigeria is said to have gone up to as high as 50 per cent (Omoh, 2015).

Prior to independence in 1960, Nigeria's education system was designed with the primary aim of serving administrative needs of the colonial master (Britain). Thus, educational systems and curricula were developed in such a way so as to effectively produce clerical and administrative officers, teachers, interpreters, clergy, guards and other liberal art graduates who would foster British westernization and the mission of colonization (Aladekomo, 2004; Nwekeaku, 2013). Consequently, Nigeria inherited a severely flawed schooling system at independence, and as such could not provide support for the country's developmental agenda.

Having inherited a flawed educational system, it behoved the Nigerian postindependence government to prioritize drastic restructuring of the system. Unfortunately, as Nwekeaku (2013) bemoaned, nothing much was done to restructure the curricula of the entire schooling system so that liberal arts continued to dominate the system, despite the multiplication of HEIs in the country. As one would expect, the demand for graduates of such disciplines in the labour market continued to be in decline, leading to a mismatch between demand and supply, and consequently to a high unemployment rate among university graduates (Akhuemonkhan et al., 2013). Moreover, these institutions are also viewed as factories for the production of white-collar job seekers lacking entrepreneurial skills (Omolayo, 2006), and even the business school students are not properly equipped with relevant skills and attributes required by a highly competitive business world 
(Nwekeaku, 2013). Consequently, about 5 million Nigerian graduates are annually released into the labour market with little or no employment opportunities (Musari, 2009).

As a way of dealing with the challenge of unemployment in Nigeria, the federal government directed all universities, polytechnics and colleges of education to include entrepreneurship education as part of their curricula, starting from the 2007/2008 academic session (Nwekeaku, 2013). For the universities, the mandate was to be implemented through the National Universities Commission, whereas the National Board for Technical Education and National Commission for Colleges of Education were responsible for the polytechnics and colleges of education, respectively. In light of this development, all HEIs in Nigeria were to run entrepreneurship studies as a compulsory course for all students, irrespective of their fields of study. The implementation of this mandate involved the design of a curriculum that is all encompassing in developing the spirit and culture of entrepreneurship (Aja-Okorie and Adali, 2013). Ultimately, the programme aims to build a learning culture that would empower the youth to take responsibility for their own future (through entrepreneurship), and acquire a good perception of the relationship between school, immediate community, business and industry (Eze and Nwali, 2012).

It is important to note that the Nigerian entrepreneurship education was a political mandate by the then administration, with little consideration for the realities on ground, and no adequate planning was involved. As Nwekeaku (2013) observed, the preparations before the commencement of the programme were hasty so that no provisions were made for a pilot scheme in some selected faculties of selected universities before full-scale implementation country wide. Also, despite the seeming urgency of the directive, Anaele et al. (2014) noted that there has been staggered implementation of entrepreneurship education in Nigeria. Before the 2011/2012 academic session, only a few universities like Covenant University, University of Benin and Obafemi Owolowo University implemented the entrepreneurship education programme in a practical manner (Eze and Nwali, 2012). Therefore, to facilitate the implementation of entrepreneurship education, the federal government, in 2011, directed all universities to set up entrepreneurship education centres on their various campuses, and these centres were tasked with the function of coordinating entrepreneurship education at each of these institutions. Furthermore, universities were also mandated to start offering courses leading to a degree in entrepreneurship starting from the 2011/2012 academic session (Eze and Nwali, 2012).

Coupled with the sluggish implementation is the misunderstanding and misinterpretation among various institutions as to what entrepreneurship education actually entails. According to Anaele et al. (2014), some institutions regard entrepreneurship studies as business or commercial subjects which should be offered to all the students, whereas some are of the opinion that entrepreneurship education entails enrolment in Vocational, Technical Education and Training. Other challenges bedevilling entrepreneurship education in Nigeria include poor curriculum design, lack of sufficient skilled manpower and lack of adequate funding from the government leading to 
unavailability of relevant resources and poor infrastructure (Agboola, 2010; Nwekeaku, 2013; Tope et al., 2014).

Perhaps having realised that entrepreneurship education alone cannot do the job, the government, in 2013, established the iDEA, as part of its efforts to reduce youth unemployment. Its establishment is in furtherance of the government's efforts to transform Nigeria into a knowledge-based and an IT-driven economy. The centre focuses on the development of technology ventures which use software development platforms to grow content, services and applications that are locally relevant as well as exportable. It provides a safe and stable environment for budding entrepreneurs to start and grow IT companies. The programme, therefore, provides support for digital entrepreneurs to develop innovative solutions that will transform the digital business environment in Nigeria and help to reduce unemployment and poverty. To meet these needs, iDEA has two programmes: the incubation and the acceleration programmes. The incubation programme, which lasts for about 12-18 months, is for the first-time entrepreneurs or very early start-up businesses, and it focuses on helping them to develop their ideas and businesses. On the other hand, the acceleration programme is a 16-week sprint focusing on rapid growth and it positions the start-ups to better attract investment. [Information Technology Developers EntrepreneurshipAccelerator(iDEA), 2013].

While there are several studies examining the role of entrepreneurship education in enhancing the entrepreneurial intentions of students, very few studies have been devoted to assessing how entrepreneurship programmes enhance actual entrepreneurial activities of its participants (Okafor et al., 2015). Furthermore, there is a paucity of studies relating to business incubators (Albort-Morant and Ribeiro-Soriano, 2015). Also, none of the existing studies on business incubation engaged Sen's capability approach, which has been considered as a more holistic approach to evaluating development programmes. Thus, very little is known about how these programmes expand the capabilities of the participants for successful entrepreneurship. Moreover, these studies do not take into cognizance the multiplicity of factors which can affect the conversion of entrepreneurial programmes into functionings. There is therefore the need for a comprehensive approach to assess the contribution of entrepreneurship programmes, taking into cognizance the multiplicity of external and internal factors.

\section{Methodology of the study}

This study engaged both qualitative and quantitative methodologies (mixed approach). Data collection was conducted from November 2015 to March 2016. Both primary and secondary data were used. The primary data were collected using semi-structured interviews and questionnaire surveys, whereas the secondary data were gathered through a review of relevant literature including journal articles on ICT, entrepreneurship and business incubators and iDEA programme documents and Nigerian government documents. Through a survey questionnaire, the study quantitatively assessed the relationship between participation in iDEA programmes and an increase in the capabilities of the tenants. On the other hand, the qualitative data collection (through semi-structured interviews) and analysis 
helped in providing in-depth understanding on how iDEA programmes expand the capabilities of participants. As observed by Blackstock et al. (2007), qualitative methodology allows for a detailed and in-depth study of cases, thus providing for the explanation and description of cause and effect, rather than proving cause and effect. Moreover, because of the small sample size (70 tenants) engaged in the study, the qualitative approach offers an additional advantage of helping to retrieve as much information as possible from the small group (Merriam, 1998). This triangulation of data made up for the lapses of small sample size as the qualitative data provided further support for the relationships observed in the quantitative data.

Sampling is simply the process of selecting observations from a given population (Babbie and Mouton, 2001). Considering the small number of iDEA tenants, the entire population was used as the sample size for questionnaire administration. Information obtained from the iDEA management indicated that there were about 70 entrepreneurs in both incubation and acceleration programmes which were the focus of this study. The decision to engage the entire population is in line with Israel (1992) who asserted that the whole population (a census) should be used when dealing with small population (less than 200). Therefore, all the iDEA tenants were selected as the sample, so that the questionnaire was administered to 70 respondents. However, only 40 respondents from the sample agreed to take part in the research. Therefore, 40 questionnaires were returned and this constituted the responses which made up the analysis.

For the semi-structured interviews, purposive sampling was used to select the respondents. According to Babbie and Mouton (2001), a purposive sample is selected on the basis of the knowledge of a population and the purpose of the study. In such sampling, a sample is selected on the basis of certain features. Therefore, for this study, a group of respondents who were perceived to be knowledgeable about the iDEA programmes were selected for the semi-structured interviews. A total number of ten respondents comprising three iDEA staff members and seven iDEA programmes' beneficiaries were interviewed. Furthermore, 20 entrepreneurial capabilities were identified from preliminary review of literature, and investigated on iDEA tenants to ascertain how the programme has enhanced participants' capabilities. The participants were asked to rate the contribution of iDEA programme towards enhancing their entrepreneurial opportunities through the 20 listed capabilities. Their responses, measured on a Likert scale from strongly disagree to strongly agree, were captured and analysed statistically. Values were assigned to the responses from 1 to 5 in the following format: strongly disagree $(\mathrm{SD})=1$, disagree $(\mathrm{DA})=2$, neutral $(\mathrm{NT})=3$, agree $(\mathrm{AG})=4$ and strongly agree $(\mathrm{SA})=5$.

Data generated were statistically analysed using the Statistical Package for the Social Sciences Version 24. According to Babbie (2007), indexes represent composite measures of variables, and these serve as efficient data analysis and data reduction devices which allow for the summarization of several indicators into a single numerical score. This study patterned after Wharton and Baron (1987), who developed an index measure to assess work satisfaction among workers, to develop the capabilities enhancement perception index 
(CEPI), which was used in assessing the contribution of iDEA programmes to enhance tenants' capabilities. Moreover, Cronbach's alpha, which is a measure of internal consistency, was used to estimate reliability of the items. Cronbach alpha values of 0.7 and above are considered acceptable (George and Mallery, 2003; Santos, 1999), offering assurance that items can be relied upon. The Cronbach alpha value obtained was 0.929 which is high above the acceptable level of 0.7 .

This study was carried out in accordance with the ethical standards for research at the University of the Western Cape. The research commenced only after the approval was granted by the relevant authorities at the University of the Western Cape. Moreover, the researchers sought the permission of the iDEA Hub management, staff and tenants before undertaking the fieldwork. The study did not cause any harm to any of the parties involved, the respondents' participation was voluntary and they could also withdraw at any time. At all the stages of data collection, the researcher made the purpose and objectives of the study clear to all the study participants. Furthermore, the researcher ensured anonymity and confidentiality, and used all data only for the intended purposes.

\section{Literature review and theoretical framework}

There is a great deal of literature both in developed and developing countries. These include research in the area of capability approach, functionings, freedoms or capabilities, business incubation and entrepreneurship development (Al-Mubaraki and Busler, 2010; Alkire, 2002; Charles and Ikenna, 2009; Asongu and Tchamyou, 2016; European Commission, 2002; Gedeon, 2010; Isaacs et al., 2007; Lalkaka, 2003; Lee and Peterson, 2000; Lee et al., 2005; Lin et al., 2011; Morris et al., 2013; Nwekeaku, 2013; Aja-Okorie and Adali, 2013; Okpara et al., 2011; Oviawe, 2010; Ratten, 2014; Robeyns, 2000, 2005; Sen, 1992; Somsuk et al., 2012; Varadjanin et al., 2014). The following sections provide a summary of literature on the capability approach and entrepreneurship education at a global level in general and Nigeria in particular.

\subsection{Sen's capability approach}

Sen's capability approach places intrinsic value on humans and argues that the ultimate aim of any developmental endeavour should be to expand the capabilities of people. The approach argues that an individual's substantive freedom (to lead a life he/she has reason to value) should be the primary aim of development, whereas economic measures should be seen as a mere means to this end. Thus, the approach strikes an analytical distinction between the means and the ends of well-being and development (Robeyns, 2005).

\subsubsection{Functionings.}

Functionings are the various aspects of life that people value. According to Conradie (2013), functionings can be defined as anything that an individual can be or do. These are the various doings and beings which humans have reasons to value.

The concept runs across the very many activities and situations which people consider important. Expanding the opportunity for these doings and beings is the focus of the 
capability approach. Some of the examples of functionings are being able to succeed academically, to think innovatively, to launch an enterprise or become an entrepreneur, to ride a bicycle and to take part in a social debate and being creative.

\subsubsection{Freedoms or capabilities.}

Sen (1992, p. 40) asserted that "capability is a set of vectors of functionings which reflects a person's freedom to lead one type of life or another." It refers to a person's or a group of persons' freedom to achieve or promote valuable functionings (Alkire, 2002, p. 121). Thus, capability or freedom reflects the genuine opportunities which one has, and can use in one way or another. For example, the fact that one has undertaken an entrepreneurship education programme does not necessarily mean that the person has effective opportunity or freedom to run a venture. This is because the student may still be constrained by lack of capital and other resources which are crucial for any entrepreneurial undertaking.

\subsection{Conversion factors in business incubation and entrepreneurship development}

The extent to which people can translate the characteristics of goods and services into capabilities is influenced by three conversion factors: personal, social and environmental characteristics (Robeyns, 2005; Sen, 1992). Personal conversion factors. An aspiring entrepreneur may be unable to maximize the learnings from his/her entrepreneurship training because of the hearing impairment which can affect his/her maximum participation in the learning environment. Such personal limitation affects the student's ability to convert the resources (entrepreneurship lecture) to functionings of being entrepreneurially knowledgeable. Robeyns (2000) noted that personal characteristics (such as physical/mental condition, metabolism and reading skills), affect how a person is able to convert the features of a commodity into a functioning. This line of thought is supported by Morris et al. (2013) who asserted that individual differences can lead to variation in how participants are affected by an entrepreneurship programme. Furthermore, the opportunity which a student has to undertake entrepreneurship education can also be seen as a personal conversion factor because the knowledge and skills acquired can influence how he/she is able to convert other resources (such as ideas, technology and finance) into the functioning of being an entrepreneur. Aja-Okorie and Adali (2013) noted this crucial role of entrepreneurship education in inculcating in the students, the skills, knowledge and attitudes required for being an entrepreneur.

Social conversion factors. Social features also play a significant role in the conversion of goods and services to functionings. According to Robeyns (2000), social characteristics (such as institutions, public policies, power relations and societal hierarchies) play a significant role in an individual's ability to convert a good's characteristics into functioning. Conradie (2013) emphasized that social issues such as race, culture, class and gender can be regarded as social conversion factors. As a mainly patriarchal society, gender discrimination is pervasive in Nigeria (Charles and Ikenna, 2009). A study by Okpara et al. (2011) on the business and social profiles of 67 women entrepreneurs in Nigeria revealed that family responsibilities are among the constraining factors which affect female 
entrepreneurship engagement. Running one's own business requires an enormous investment of time and resources. If women are expected to be preoccupied with housework, it may inhibit their chances of starting their own enterprises. Furthermore, a culture that sees women as mainly housekeepers will not be a conducive environment for creating the right mindset necessary for female entrepreneurship activities. If, for example, a young girl is socialised into thinking that business ownership is an exclusive preserve of men, her chances of venturing into entrepreneurship later in life will be limited. The impact of sociocultural factors on entrepreneurship engagement is best articulated by Lee and Peterson (2000) who argued that great entrepreneurs do not develop by themselves, but are rather the products of entrepreneurship-oriented societies and cultures. Furthermore, Lee et al. (2005) asserted that "entrepreneurs are cultivated during their lifetime, and that social and cultural environment, personal experience, and education are very important to building entrepreneurship.”

Environmental conversion factors. These deal with infrastructural limitations such as inadequate infrastructure and teaching and learning environment, entrepreneurially unfriendly fiscal and monetary policies, government regulations, poor library facilities and lack of access to loans and start-up funds. Business ideas can be likened to seeds which require the right soil conditions for germination. When these conditions are not in place, the probability of growth is severely hampered. Isaacs et al. (2007) asserted that exogenous factors such as access to finance, infrastructure and favourable business environments affect the translation of entrepreneurial intentions, knowledge and skills into entrepreneurial activities. For example, it has been noted that the poor state of infrastructure in Nigerian universities cannot support the newly introduced entrepreneurship education (Nwekeaku, 2013; Oviawe, 2010). On the other hand, Asongu and Tchamyou (2016) found that there is an inverse relationship between the time required to start a business and the level of innovation. An aspiring entrepreneur may be dissuaded by several bureaucratic huddles which must be crossed in starting a business.

Critique of the capability approach. A major critique of Sen's capability approach regards the lack of a specific set of capabilities (Nussbaum, 2003). Some scholars consider the approach as an unworkable idea, whereas others accuse the approach of being insufficiently specified (Robeyns, 2000). The consequence of this lack of a capability list is that any evaluative framework making use of the approach will need to do its selection of valuable functionings. It is argued that the challenge also threatens the operationalization of the approach. However, Sen argued that leaving the capability approach "incomplete" rather than having it prescriptive and precise like most other development theories is intentional, and that is so it could serve a wide range of purposes (Robeyns, 2005). In this study, while a preliminary list of capabilities was developed from the literature research, the researcher also engaged Sen's notion of democratic process in developing a list of relevant capabilities for digital entrepreneurship. This was achieved by giving the participants the opportunity to identify various factors and situations which influence success in digital entrepreneurship. 


\subsection{Expanding capabilities through business incubation}

As stated before, the capability approach focuses on the effective opportunities which people have to do and to become what they value. Goods and services are considered important only to the extent that their characteristics enable people to do and to be what they value, that is, in the light of the capabilities which one can generate from these goods and services (Robeyns, 2005). As noted before, entrepreneurship education enhances entrepreneurial capabilities by improving the knowledge and skills of aspiring entrepreneurs. However, the demands of entrepreneurial undertaking go beyond the knowledge and skills. According to Bøllingtoft (2012), most start-ups are unable to make it through their formative years because of numerous liabilities resulting from their being new in the ecosystem as well as being small; all of which reduce their chances of breaking through various obstacles along their path. They are not only faced with lack of requisite knowledge and skills but also have to waddle their way through lack of infrastructure, finance and other resources, which are critical to developing an idea into a product, and bringing a product to market (Lin et al., 2011; Somsuk et al., 2012).

According to Al-Mubaraki and Busler (2010), business incubators bridges this lacuna by providing a mixture of tangible and intangible services, which include access to physical space, administrative assistance, coaching, consulting, training, networking and financing. By providing adequate support to firms at the early stage of development, incubators compensate for the deficiencies faced by these ventures, thereby helping to boost their survival rate and growth prospect (Lalkaka, 2003). This claim is supported by the European Commission (2002) which asserted that incubation assists start-ups to maximise growth potential in a manner that is difficult for other SME support structures to achieve. Consequently, it can be argued that business incubation expands entrepreneurial capabilities beyond mere entrepreneurship learning because it provides access to other relevant resources. This capability set includes certain entrepreneurial and managerial competencies (Morris et al., 2013), as well as access to relevant physical, informational, financial and other resources needed for entrepreneurial success (Van Aardt et al., 2008).

\subsubsection{Entrepreneurship.}

There is no consensus on the correct definition of entrepreneurship among various scholars (Gedeon, 2010; Nwekeaku, 2013; Varadjanin et al., 2014). However, this paper will present a number of definitions offered by different scholars to point out certain characteristic features of entrepreneurship. To begin with, it may be helpful to define entrepreneurship by defining the person who carries out the role of entrepreneurship, that is, the entrepreneur. According to Kirzner (1997), an entrepreneur is a decision maker whose role arises from being alert to previously unnoticed opportunities. He or she is that person who creates an organization to pursue a perceived opportunity (Bygrave and Hofer, 1991). From these definitions, it can be deduced that an entrepreneur must have certain qualities. The first is the ability to see the opportunities, the second is the willingness to exploit such opportunities and the third is the capability (knowledge, skills, etc.) to exploit the perceived opportunities through business formation. 
The journey of an entrepreneur is encapsulated in the word "entrepreneurship" which comes from the French word entreprendre, meaning to undertake something or to do something (Varadjanin et al., 2014). According to Churchill (1992), entrepreneurship can be defined as the process of uncovering and developing an opportunity so as to create value through innovation, either through the formation of a new business or within an already existing company. Gedeon (2010) provided a more comprehensive definition of entrepreneurship:

Entrepreneurship is a multi-dimensional concept that includes owning a small business, being innovative, acting as a leader, or starting up a new company. It includes spotting opportunities to drive the market toward equilibrium or causing disequilibrium through creative destruction. It includes doing this on your own, in a team or inside a company. It involves starting without any resources and creating new values in the realm of business, social values, government or academia (Gedeon, 2010, p. 30).

This definition brings to the table the various aspects of entrepreneurship. The first of these is the leadership dimension or proactivity. An entrepreneur must set himself/herself apart as a leader by identifying the "hidden" opportunities and channelling his/her will power and resources towards creating value from such opportunities. It also highlights the fact that one does not need to start an entirely new venture to be an entrepreneur. This is because an entrepreneur can still operate within an already existing company by, for example, altering the manner in which business is done in that firm.

\subsubsection{Boosting entrepreneurship through education and training.}

Various studies have shown that there is a positive relationship between entrepreneurship education/training and entrepreneurial success (Herrington et al., 2011; Isaacs et al., 2007; Robertson et al., 2003; Lee et al., 2005). Education is known to have a strong positive influence on the entrepreneurial performance of any country (Robinson and Sexton, 1994). It is regarded as a key factor in establishing a culture of entrepreneurship (Steenekamp et al., 2011).

Contrary to the notion that entrepreneurs are born, a longitudinal study by Penaluna et al. (2011) revealed that, through entrepreneurship education, entrepreneurship can be taught, or at least enhanced. This position is corroborated by Kuratko (2005) who noted that entrepreneurial ability is neither mystical nor magical but something that could be learned. Entrepreneurship education is a means of raising awareness of students of the value and nature of entrepreneurship, as well as delivering skills and knowledge. It is through education and training that the required human capacity for successful entrepreneurial engagement is developed. Therefore, a country with qualitative entrepreneurial education will likely produce successful entrepreneurs. However, some scholars have argued that biological factors and family environment can also influence entrepreneurial engagements. For example, Carr and Sequeira (2007), in a US study, found significant indirect and direct effects of prior family business exposure on future entrepreneurial intention. 
According to Akhuemonkhan et al. (2013, p. 64), entrepreneurship education refers to a set of specialised knowledge which inculcates into learners the traits of innovation, risk- taking, arbitrage and coordination of factors of production with the aim of creating new products and services for both new and existing users within human communities. Gedeon (2014) defined the term as a means of empowering students with a philosophy of entrepreneurial thinking passion and action-orientation which they can apply to their lives, communities, jobs and/or their own new ventures. It is the process of altering the mindset of students towards applying an innovative approach and creative thinking to proffer solutions to societal problems, assuming responsibility for both profit and risk, and thereby creating employment for others. Entrepreneurship education, therefore, aims to alter the beliefs and attitudes of learners while equipping them with the entrepreneurial skills and knowledge requisite for success in business. On the other hand, entrepreneurship training involves imparting relevant skill and knowledge through regular practice and instruction. According to Stanger (2004), entrepreneurial training can be defined as an educational course or class which imparts business or vocational knowledge and skills to participants.

\subsubsection{Challenges to entrepreneurship education in Nigeria.}

The inability of entrepreneurship education to yield the desired fruits of enhancing entrepreneurial engagement, boosting job creation and reducing unemployment and poverty can be attributed to a number crippling factors. According to Tepa et al. (2014), because of high inequality in Nigeria, many aspiring entrepreneurs lack the required capital to start up their ventures, and assessing bank loans is very challenging because of strident conditions. Agboola (2010) also asserted that young entrepreneurs in Nigeria suffer from the inaccessibility of soft loans and funding. Moreover, the various HEIs suffer from inadequate or outright lack of funding for the effective implementation of the entrepreneurship education. This situation is further highlighted by Nwekeaku (2013) who described the poor state of infrastructure in Nigerian universities as worrisome and as such cannot support the newly introduced entrepreneurship education. Because of these severe infrastructural deficiencies, the Nigerian environment is not conducive for start-up businesses (Adenikinju, 2003, 2005; Mohammed et al., 2013; Okafor, 2008) so that the students are unable to translate entrepreneurial learnings into business ventures. A recent publication by World Bank (2016) revealed that Nigeria ranks 169 in ease of doing business, a one-point improvement from its previous 170th position.

\section{Results and analysis of empirical findings}

The study developed indexes to measure the perception of the respondents, on how iDEA programmes have enhanced their entrepreneurial capabilities. The average CEPI, denoted as CEPI, is approximately 3.90, representing the aggregate level of respondents' perception of the extent to which iDEA programmes have enhanced their entrepreneurial capabilities. From the above analysis, it is clearly evident that the capabilities enhancement perception is above "neutral" (rated " 3 " on the Likert scale). Taking 3.0 to be the average rating (calculated as $[\mathrm{I}+2+3+4+5] / 5$ ), it can be concluded that the beneficiaries perceived that the iDEA programmes have enhanced their entrepreneurial capabilities. 
Furthermore, looking at the mean deviation (CEPI - CEPI ), it can be observed that 11 of the variables have a negative deviation about CEPI, whereas nine variables have a positive deviation about CEPI (Table I). Also while access to power supply (0.75) and reliable internet (0.68) has the highest positive deviations, negotiation skills (-0.55) and access to customers/clients (-0.5) have the highest negative deviation.

It can therefore be concluded that the participants of the iDEA programmes mostly benefited in the areas of access to reliable electric power and internet, whereas the contribution of iDEA programmes to the participants' negotiation skills and access to customers/clients were limited. These findings are well corroborated by the qualitative analysis in which the participants unequivocally narrated how the resources provided by iDEA aided them in their entrepreneurial endeavours.

First, iDEA provides office space for the aspiring and emerging entrepreneurs to carry out their business activities. The centre does not only provide a conducive physical space with basic amenities (e.g. electrical power supply) but also provides access to high-speed internet. As one of the participants explained:

IDEA being so kind, they provide office arrangement, power, water is provided, there is security, internet [...] if you have to source for those things on your own, you may not be able to afford them as a start-up [...] in Nigeria basic infrastructure is non-existent [.. .] for a digital entrepreneur, the most important things are office space, internet and power, and in that regard, iDEA has provided the three basic things needed ( $\mathrm{P}_{5}$ : iDEA tenant).

Another respondent explained:

IDEA provides infrastructural support [...] power is no longer an issue when you come to iDEA because for the entire day, I will have power [.. .] in my house, even when you have money to buy fuel (petrol) for generator, you may not find fuel(petrol) [.. .] but when you come to iDEA, there will be light (electricity), that gives you a little bit of balance to work [...] you have stable reliable internet [... . these two major issues are cut out of lines of worries (P7: iDEA tenant).

It is clearly evident that despite the fact that office space, electrical power and internet are indispensable resources for any digital entrepreneur, the Nigerian entrepreneurial environment suffers severely from the lack of these basic amenities (Adomi, 2005; Mohammed et al., 2013; Okafor, 2008). The deficiency of these environmental conversion factors can impede the translation of entrepreneurial desire, skills and knowledge into the functioning of running a successful tech business. These quotes are not only indicative of the indispensability of these resources but also give credence to the fact that iDEA enhances access to these, and as such is in tandem with the findings mentioned in Table I. 
However, the offices provided by iDEA serve not only as a working space for the tenants but also as a stamp of authenticity and credibility for the emerging entrepreneurs who use iDEA as their official business address. As noted by one of the respondents:

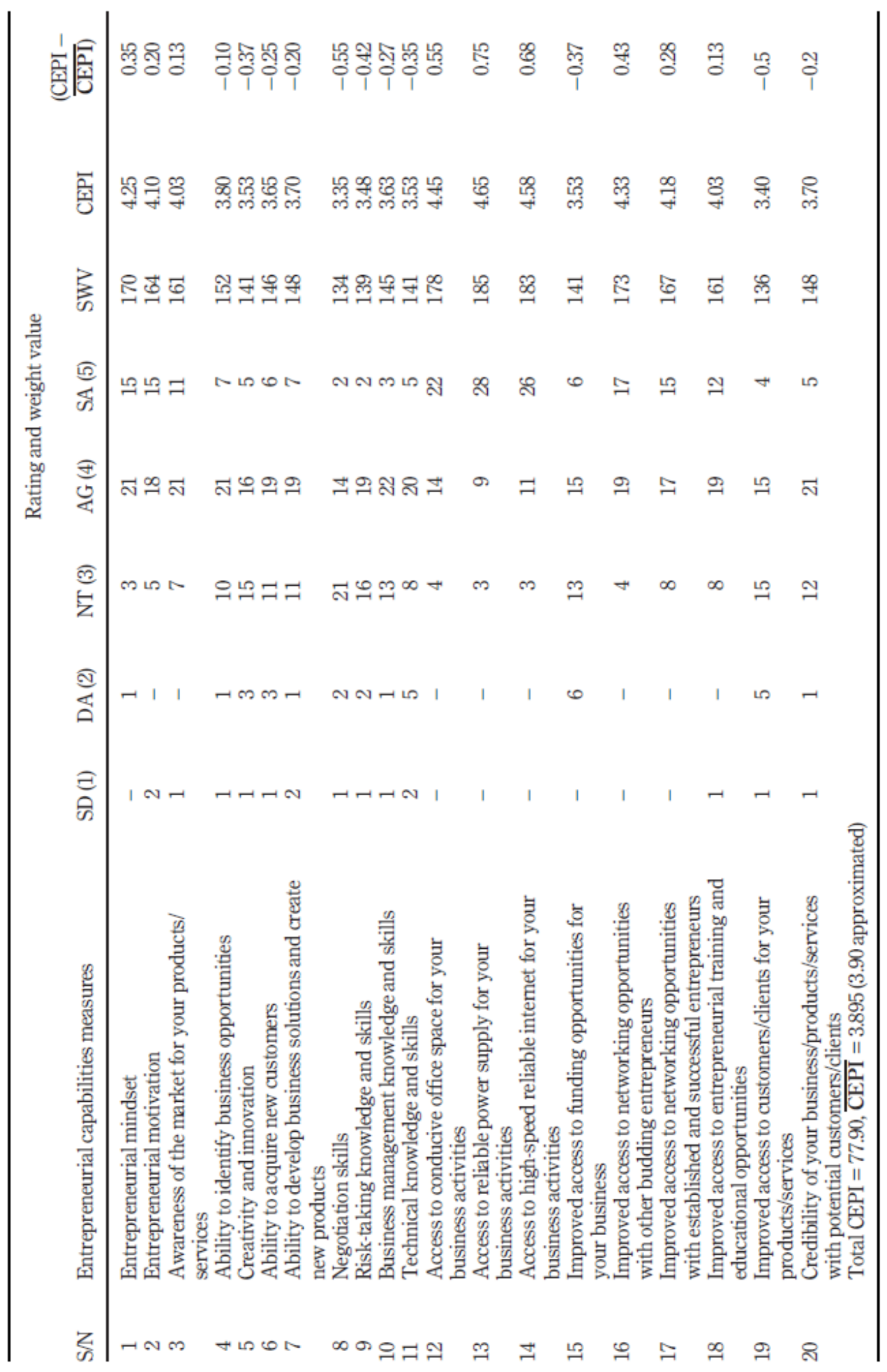

Table I. Calculation of the capability enhancement perception index 
[...] all my cards and marketing materials have iDEA hub as address [...] Nigerians will not want to do business with you if they can't see any legit (legitimate) address [...] (P6: iDEA tenant). Second, it was also noted that a significant proportion of iDEA's annual budget is spent on providing these basic resources, and this shows that the management of iDEA understands the crucial role they play in the lives of the entrepreneurs:

[...] It is money-intensive to run it [...] we burn through about 70 million Naira a year. And about 40 per cent of that goes to rent and bandwidth (internet). We do about 30 million Naira for bandwidth and rent of this place. (P1: iDEA staff).

In spite of the huge cost of these resources, iDEA makes it accessible to the entrepreneurs at a very subsidized rate which is charged in the form of an entry fee. As one of the participants narrated:

[...] and what you pay (at iDEA) is a very little amount compared to what you will spend on your own [...] you have everything that you want [...] there is office space, there is internet, and there is light (electricity). And we all know that light is a major thing because outside there, you have to run on gen (generator) and that is very expensive (P8: iDEA tenant).

Considering that Nigeria suffers massively from an infrastructural deficiency (Adenikinju, 2003, 2005; Mohammed et al., 2013), it is not surprising that the respondents attached great significance to these resources provided by iDEA. Part of the capability approach's aim is to emphasize contextual differences because these have a significant effect on a person's opportunity to achieve valuable functionings. For example, having a reliable electricity supply may be a non-issue for a start-up located in New York City, but for a business in Lagos, it is a big challenge.

Furthermore, the iDEA environment enhances networking among budding entrepreneurs in a mutually beneficial manner. By bringing together in one place, a pool of varying talents, knowledge and abilities, iDEA enhances skills complementation among its tenants. As one of the respondents recounted:

[...] it gives you access to an exclusive group of talents [...] we have start-ups here that are very exceptional in one thing or the other [.. .] programming, graphic design, so you can say I need help with this [...] they might not charge you, they may charge you very little compared to what you get outside [...] so you have access to the best talents here [...] also they are encouraging you [...] giving you something to look up to, giving you reasons to work harder $[\ldots .$.$] it's like a family here ( \mathrm{P}_{5}$ : iDEA tenant).

From this account, it is clear that the iDEA environment encourages various forms of symbiotic relationships and beneficiation among its tenants. In this way, these are able to both complement and motivate each other towards their entrepreneurial goals. Numerous scholars have highlighted the role of social networks in providing entrepreneurs with a wide 
range of valuable resources that enable the achievement of entrepreneurial success (Casson and Giusta, 2007; Ripollés and Blesa, 2005; Welter and Kautonen, 2005). According to Klyver et al. (2008), social network provides access to relevant information, finance, skills, knowledge and advice.

Third, beyond enhancing networking among budding entrepreneurs, iDEA also linkstheir tenants with established external entrepreneurs through their mentoring programmes and special events. Klyver et al. (2008) noted that such network helps to boost an entrepreneur's social legitimacy, reputation and credibility. These benefits were observed in the study as evident in one of the respondent's accounts below:

[.. .] they have a very vast network which I am still trying to tap into [.. .] that network allows you access to a lot of potential clients, a lot of mentors, a lot of people you can work with at affordable prices [...] they have a very vast network that is useful to every start-up [...] being with iDEA Hub makes the journey fifty per cent easier at least [.. .] they gave me something that I could not have found elsewhere and that is the credibility, so now I have big clients [.. .] when we first started, people will do business with you even when they don't know you because they know that you are with a reputable government organization [...] we had a client that paid us off front up to a million Naira when we started because the credibility was coming from iDEA [...] so it gives a lot of credibility to the start-ups ( $\mathrm{P}_{5}$ : iDEA tenant).

Another respondent narrated:

[...] by being in iDEA, you have unimpeded access to other businesses, and iDEA can refer you to very big companies [.. .] iDEA has access to the top CEOs in the business, and being that iDEA is government sponsored, we somehow have indirect access to the Ministry of ICT and Ministry of Science and Technology [...] (P9: iDEA tenant).

By learning from these established businesses, the tenants are equipped with knowledge gleaned from years of experience so that they are better prepared to make informed decision. For some of the tenants, access to valuable networks is one of the most important capabilities they gain from iDEA, and this is in consonance with the findings mentioned in Table I:

[...] the benefits are more on the exposure to opportunities, networking and knowledge [.. .] bringing very experienced people who come [...] they share real information that applies to your market $[. .$.$] we also have access to mentors who answer your questions and help you by$ sharing valuable experiences [...] in the second week of December for example, the CEO of Etisalat, which is the fourth biggest telecom company in Nigeria was here in iDEA with his top executives [...] we met with him and he team and he was giving us feedback and connecting us with their team since our product is telecom based (P10: iDEA tenant). 
For the iDEA management, this facilitation of networking and collaboration within the technology ecosystem is a major goal of the organization:

What we do [...] is strengthening the ecosystem; making sure that everybody in the system is collaborating and working together. That is what we see as one of our main [...]? (P1: iDEA staff).

Fifth, iDEA provides training to the entrepreneurs as a way of equipping them with requisite skills and knowledge for developing digital products and services. As recounted by one of the iDEA staff:

[...] we run our tech training here. And we have tech clinic to check the quality of the product. Everything starts with product. If you have a good entrepreneur and bad product, it doesn't really help you [...] (P1: iDEA staff).

However, some of the respondents were of the view that iDEA programmes did not have much direct impact on their technical skills, thus corroborating the finding mentioned in Table I that the effects of iDEA programmes on the IT skills of participants is roughly average. Nevertheless, by providing a space where people of varying skills and talents work together, tenants are able to learn from one another. This indirect contribution via networking is encapsulated in the accounts of the two respondents below:

[...] in terms of technical knowledge no [...] I have not learnt any additional technical skills from iDEA [...] but there is one thing, challenge, you know when you are in the midst of other people that are doing similar thing as you, you are challenged to do more, and then you can have one or two discussion with other entrepreneurs [.. .] spark you up to do something that you might not even have thought about if you were outside the programme [...] two is better than one anyway [...] and then bringing ten in one place [...] they tend to mingle and share ideas and they build an empire that would not have built outside (P4: iDEA tenant).

IDEA can help with imparting knowledge [.. .] even if not directly through iDEA but by interacting with fellow start-ups, you hear what they are doing, you see what they are doing, you see how they are solving their own problems, and you know that you can borrow one or two ideas from them, and incorporate one or two strategies they have done, and it helps you to minimise your risks and your losses (P9: iDEA tenant).

Sixth, iDEA also provides access to funding opportunities so as to enable entrepreneurs with promising ideas to turn those into reality:

[... .] trying to get the entrepreneur open to sources of capital [...] the president of Lagos Angel Network is also the chairman of iDEA board which is quite good for us, and the biggest issue is we have money but the ventures are not investment ready, so our job is to make sure they are investment ready and then connect them to the money so we have a 
strong relationship with LAN. We are also trying to expose them to all sorts of competitions that will enable them with all sorts of grants and prizes and a couple of them within the Hub have gotten $\$ 5,000$ here, $\$ 10,000$ here to help them as they continue to grow their product. We are also trying to expose them to partnership with corporate [...] (P1: iDEA staff).

It is evident from the account above that iDEA has access to various funding opportunities. However, the challenge remains that of assisting the tenants to develop viable products and services which are worthy of investment, and this explains why only about half of the respondents (from the quantitative analysis) agreed that iDEA has improved their access to funding opportunities.

Moreover, the respondents were of the view that iDEA programmes improved their business skills in various dimensions. As explained by one of the respondents:

IDEA entrepreneurship booth camp opened my eyes [... .] it made me to know how to identify customers [.. .] it made me to start asking questions [.. .] study your market very well... and that was how the whole journey began (P8: iDEA tenant).

One member of the iDEA staff noted:

IDEA is doing a great job in providing them with access to relevant updated information on how to go about successful digital entrepreneurship (P2: iDEA staff).

The analysis presented above is evident that iDEA programmes have contributed positively towards the expansion of participants' opportunities for entrepreneurial success). This result is also in consonance with works of numerous scholars (Al-Mubaraki and Busler, 2010; Bergek and Norrman, 2008; Bubou and Okrigwe, 2011; Lesákova, 2012) who asserted that business incubators provide a conducive environment for new firms to thrive through an array of resources and services being offered to them.

\section{Conclusion}

Sen's capability approach brings to light the fact that great ideas do not guarantee great businesses. Neither does entrepreneurial knowledge alone guarantee success in entrepreneurship. In the same vein "great" entrepreneurship programmes do not guarantee improved entrepreneurship performance of a country owing to a multiplicity of interacting factors. For entrepreneurship to thrive, not only is there a need for relevant support structures but also the implementation of these structures must take into cognizance the diversity of societies and individual entrepreneurs. Beyond entrepreneurship education, the iDEA incubator provides access to relevant resources which can serve as conversion factors along the journey towards entrepreneurial functionings. This is achieved by providing tenants with access to relevant infrastructure such as internet, office space and funding. The centre provides critical and significant resources and services to aspiring and emerging digital entrepreneurs. Bearing in mind that these resources and services are deficient in Nigeria, one cannot deny the contribution of iDEA towards the development of digital 
enterprises in Nigeria. The Hub serves as a laboratory for boosting technology entrepreneurship capabilities in Nigeria. However, it should be noted that incubators may not be able to deal with environmental conversional factors (such as fiscal/monetary policies, political instability and currency volatility) and social conversion factors (e.g. gender discrimination). Nonetheless, a comprehensive approach to entrepreneurship development necessitates taking cognizance of these multiple factors, and creating programmes to address these.

This study makes a number of contributions to entrepreneurship literature. First, the study is a debut of research endeavours which theoretically assess entrepreneurship programmes via the capability approach lens. It developed a conceptual model for assessing business incubation using the capability approach, as illustrated by the means of a diagram appearing in Figure 1 adapted from Robeyns's study (2005, p. 98). Second, through the review of relevant literature and empirical analysis, the study provides a list of capabilities required for entrepreneurial success. It is important to note that the list is not exhaustive so that more could be included; also bearing in mind that the capabilities ought to be contextdependent. By developing a tool for the assessment of business incubation, the study aims to broaden understanding of the outcomes of incubation programmes. It is hoped that it would stimulate future research examining business incubators and other entrepreneurship programmes through the capability approach. Moreover, considering the severe deficiency of these resources in Nigeria, this paper suggests an integration of business incubation into the current entrepreneurship education for greater effectiveness. It is also hoped that the result of this research will inform the development of more effective and holistic entrepreneurship development programmes.

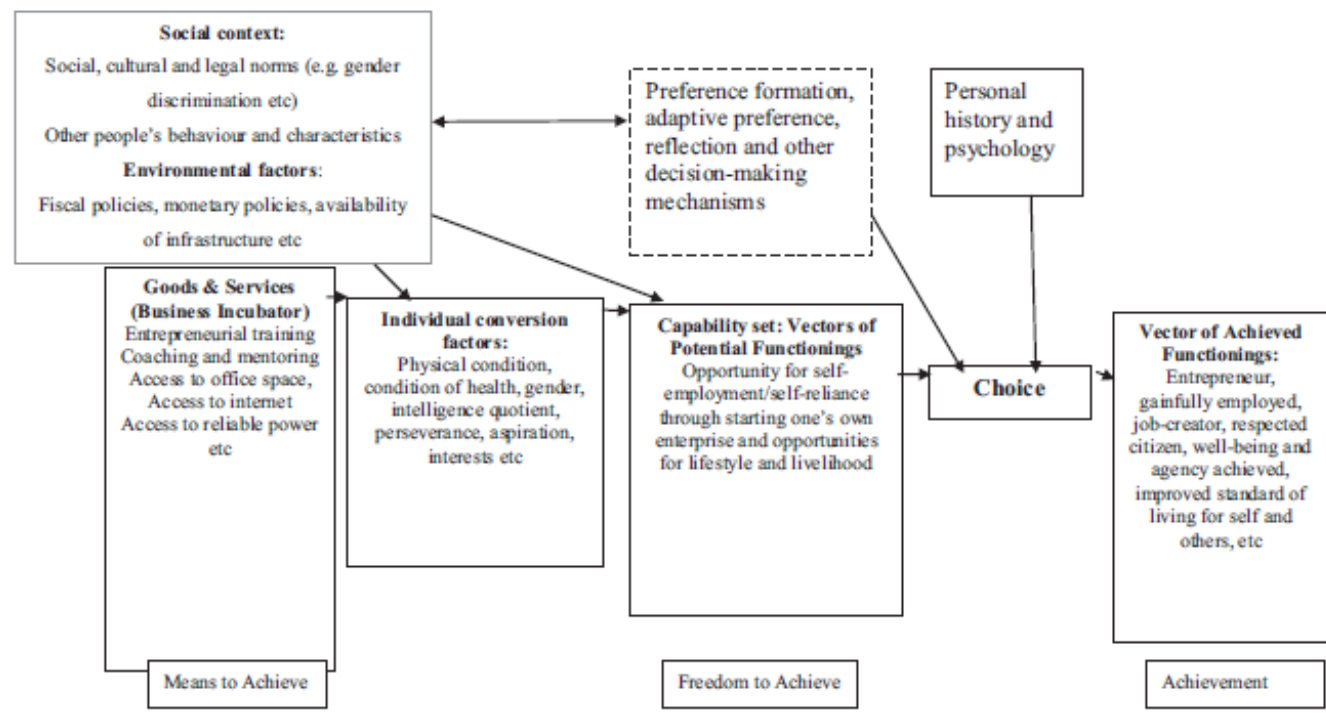

Source: Adapted from Robeyns (2005, p. 98)
Figure 1. Conceptual model of capability approach and entrepreneurship development through business incubation 


\section{References}

Acs, Z. (2006), "How is entrepreneurship good for economic growth?”, Innovations, Vol. 1 No. 1, pp. 97-107.

Acs, Z.J., Desai, S. and Hessels, J. (2008), "Entrepreneurship, economic development and institutions", Small Business Economics, Vol. 31 No. 3, pp. 219-234.

Adenikinju, A.F. (2003), "Electric infrastructure failures in Nigeria: a survey-based analysis of the costs and adjustment responses", Energy Policy, Vol. 31 No. 14, pp.1519-1530.

Adomi, E.E. (2005), “Internet development and connectivity in Nigeria”, Program, Vol. 39 No. 3, pp. 257-268.

Agboola, B.M. (2010), "Entrepreneurial education in Nigeria tertiary institutions and sustainable development”, available at: http://files.eric.ed.gov/fulltext/ED512732.pdf (accessed 11 March 2016).

Aja-Okorie, U. and Adali, O. (2013), "Achieving youth empowerment through repositioning entrepreneurial education in Nigerian universities: problems and prospects", European Scientific Journal, Vol. 9 No. 28.

Akhuemonkhan, I.A., Raimi, L. and Sofoluwe, A.O. (2013), "Entrepreneurship education and employment stimulation in Nigeria", Journal of Studies in Social Sciences, Vol. 3 No. 1.

Aladekomo, F.O. (2004), "Nigeria educational policy and entrepreneurship", Journal of Social Science, Vol. 9 No. 2, pp. 75-83.

Alkire, S. (2002), Valuing Freedoms: Sen's Capability Approach and Poverty Reduction, Oxford University Press, Oxford.

Al-Mubaraki, H.M. and Busler, M. (2010), "Business incubators findings from a worldwide survey, and guidance for the GCC states”, Global Business Review, Vol.11 No. 1, pp.1-20.

Arokiasamy, A.R.A. (2012), "The influence of globalization in promoting entrepreneurship in Malaysia", South East European Journal of Economics and Business, Vol. 7 No. 2, pp.149-157.

Asongu, S.A. and Tchamyou, V.S. (2016), "The impact of entrepreneurship on knowledge economy in Africa”, Journal of Entrepreneurship in Emerging Economies, Vol. 8 No. 1, pp.101-131.

Babbie, E. (2007), The Practice of Social Research, Thomson Wadsworth, Belmont, CA.

Bakar, R., Islam, M.A. and Lee, J. (2015), "Entrepreneurship education: experiences in selected countries", International Education Studies, Vol. 8 No. 1, p. 88.

Bøllingtoft, A. (2012), "The bottom-up business incubator: leverage to networking and cooperation practices in a self-generated, entrepreneurial-enabled environment", Technovation, Vol. 32 No. 5, pp. 304-315.

Bubou, G.M. and Okrigwe, F.N. (2011), "Fostering technological entrepreneurship for socioeconomic development: a case for technology incubation in Bayelsa State, Nigeria", Journal of Sustainable Development, Vol. 4 No. 6, pp. 138-149.

Bygrave, W. and Hofer, C. (1991), "Theorizing about entrepreneurship", Entrepreneurship Theory and Practice, Vol. 16 No. 2, pp. 13-22.

Carr, J.C. and Sequeira, J.M. (2007), "Prior family business exposure as intergenerational influence and entrepreneurial intent: a theory of planned behavior approach", Journal of Business Research, Vol. 6o No. 10, pp. 1090-1098. 
Carree, M.A. and Thurik, A.R. (2010), "The impact of entrepreneurship on economic growth", International Handbook Series on Entrepreneurship, Vol. 1 No. 7, pp. 437-471.

Casson, M. and Giusta, D.M. (2007), "Entrepreneurship and social capital Analysing the impact of social networks on entrepreneurial activity from a rational action perspective", International Small Business Journal, Vol. 25 No. 3, pp. 220-244.

Charles, I.E. and Ikenna, M.A. (2009), "Electoral process and gender discrimination in Nigeria: a case study of 2003 and 2007 general elections", Journal of Sustainable Development in Africa, Vol. 10 No. 4, pp.113-128.

Chimucheka, T. (2014), "Entrepreneurship education in South Africa”, Mediterranean Journal of Social Sciences, Vol. 5 No. 2, p. 403.

Churchill, N. (1992), "Research issues in entrepreneurship", in Sexton, D. and Kasarda, J. (Eds), The State of the Art of Entrepreneurship, PWS-Kent, MA, Boston, pp. 579-596.

Conradie, I. (2013), "Can deliberate efforts to realise aspirations increase capabilities? A South African case study", Oxford Development Studies, Vol. 41 No. 2, pp. 189-219.

Edmond, A.O., Oluniyi, A.A., Dem Isaiah, I.M. and Barfa, G.I. (2014), "Strategies for revitalizing the implementation of entrepreneurship education in technical, vocational education and training (TVET) to enhance self-employment in Nigeria”, British Journal of Education, Vol. 2 No. 4, pp. 50-62.

Edoho, F.M. (2016), "Entrepreneurship paradigm in the new millennium: a critique of public policy on entrepreneurship", Journal of Entrepreneurship in Emerging Economies, Vol. 8 No. 2, pp. 279-294.

European Commission (2002), "Final report: benchmarking of business incubators", available at: www. cses.co.uk/upl/File/Benchmarking-Business-Incubators-main-report-Part1.pdf (accessed 6 March 2016).

Eze, J.F. and Nwali, A.C. (2012), "Capacity building for entrepreneurship education: the challenge for the developing nations", American Journal of Business Education, Vol. 5 No. 4, pp. 401-408.

Gedeon, S. (2010), "What is entrepreneurship?", Entrepreneurial Practice Review, Vol. 1 No. 3.

George, D. and Mallery, M. (2003), Using SPSS for Windows Step by Step: A Simple Guide and Reference, 11.0 update 4th Ed., Allyn \& Bacon, Boston.

Global Entrepreneurship Monitor (GEM) (2008), "Executive report", available at: http://gemconsortium. org/report/47107 (accessed 19 July 2017).

Harry Matlay, P., Rae, D. and Ruth Woodier-Harris, N. (2013), "How does enterprise and entrepreneurship education influence postgraduate students' career intentions in the New Era economy?”, Education Training, Vol. 55 Nos 8/9, pp. 926-948.

Herrington, M., Simrie, M., Kew, J. and Turton, N. (2011), "Global entrepreneurship monitor South Africa", available at: www.gsb.uct.ac.za/files/GEM2011Report.pdf (accessed 1 May 2016).

Information Technology Developers Entrepreneurship Accelerator (iDEA) (2013), iDEA Nigeria: Year End Report, Lagos.

Inyang, B.J. and Enuoh, R.O. (2009), "Entrepreneurial competencies: the missing links to successful entrepreneurship in Nigeria”, International Business Research, Vol. 2 No. 2, p. 62. 
Isaacs, E., Visser, K., Friedrich, C. and Brijlal, P. (2007), "Entrepreneurship education and training at the further education and training (FET) level in South Africa", South African Journal of Education, Vol. 27 No. 4, pp. 613-630.

Israel, G.D. (1992), "Determining sample size. university of Florida Cooperative extension service, institute of food and agriculture sciences, EDIS", available at: http://citeseerx.ist.psu.edu/ viewdoc/download?doi=10.1.1.564.9215\&rep=rep1\&type=pdf (accessed 25 March 2016).

Kirzner, I. (1997), "Entrepreneurial discovery and the competitive market process: an Austrian approach", Economic Literature, Vol. 25 No. 1, pp. 60-85.

Klyver, K., Hindle, K. and Meyer, D. (2008), "Influence of social network structure on entrepreneurship participation - a study of 20 national cultures", International Entrepreneurship and Management Journal, Vol. 4 No. 3, pp. 331-347.

Lalkaka, R. (2003), "Business incubators in developing countries: characteristics and performance",

International Journal of Entrepreneurship and Innovation Management, Vol. 3 Nos 1/2, pp. 3155 .

Lee, S.M. and Peterson, S.J. (2000), "Culture, entrepreneurial orientation, and global competitiveness", Journal of World Business, Vol. 35 No. 4, pp. 401-416.

Lee, S.M., Chang, D. and Lim, S.B. (2005), "Impact of entrepreneurship education: a comparative study of the US and Korea", The International Entrepreneurship and Management Journal, Vol. 1 No. 1, pp. 27-43.

Ligthelm, A.A. (2008), "A targeted approach to informal business development: the entrepreneurial route", Development Southern Africa, Vol. 25 No. 4, pp. 367-382.

Matlay, H. (2008), "The impact of entrepreneurship education on entrepreneurial outcomes", Journal of Small Business and Enterprise Development, Vol. 15 No. 2, pp. 382-396.

Mitra, J., Abubakar, Y.A. and Sagagi, M. (2011), "Knowledge creation and human capital for development: the role of graduate entrepreneurship", Educationp Training, Vol. 53 No. 5, pp. 462-479.

Mohammed, Y.S., Mustafa, M.W., Bashir, N. and Mokhtar, A.S. (2013), "Renewable energy resources for distributed power generation in Nigeria: a review of the potential", Renewable and Sustainable Energy Reviews, Vol. 22, pp. 257-268.

Morris, M.H., Webb, J.W., Fu, J. and Singhal, S. (2013), "A competency-based perspective on entrepreneurship education: conceptual and empirical insights", Journal of Small Business Management, Vol. 51 No. 3, pp. 352-369.

Musari, A. (2009), "Youth and the national youth employment action plan, Abuja", The Guardian, Nigeria, 19 March.

Naudé, W. (2011), "Entrepreneurship and economic development: an introduction", Entrepreneurship and Economic Development, Palgrave Macmillan, Basingstoke.

Nussbaum, M. (2003), "Capabilities as fundamental entitlements: Sen and social justice", Feminist Economics, Vol. 9 Nos 2/3, pp. 33-59.

Nwekeaku, C. (2013), "Entrepreneurship education and challenges to Nigerian universities", Journal of Education and Practice, Vol. 4 No. 3, pp. 51-56.

Okafor, E.E. (2008), "Development crisis of power supply and implications for industrial sector in Nigeria”, Journal of Tribes and Tribals, Vol. 6 No. 2, pp. 83-92. 
Okafor, C., Ola-David, O., Oluwatobi, S., Oludayo, O.O., Akinbode, M. and Achugamonu, B. (2015), "Entrepreneurship education and poverty alleviation: impact analysis of covenant university graduates between 2006-2013", available at: http://eprints.covenantuniversity.edu.ng/5343/1/ Paper\%2085.pdf (accessed 6 August 2016).

Okpara, J.O., Halkias, D., Nwajiuba, C., Harkiolakis, N. and Caracatsanis, S.M. (2011), "Challenges facing women entrepreneurs in Nigeria", Management Research Review, Vol. 34 No. 2, pp. 221-235.

Omoh, G. (2015), "Youth unemployment in Nigeria up to 50\%- Mckinsey \& Co.", Vanguard, 26 January, available at: www.vanguardngr.com/2015/o1/youth-unemployment-nigeria50-mckinsey-co/ (accessed 28January 2016).

Omolayo, B. (2006), "Entrepreneurship in theory and practice", in Omotosho, F., Aluko, T.K.O, Wale Awe, O.I. and Adaramola, G. (Eds), Introduction to Entrepreneurship Development in Nigeria, University of Ado-Ekiti Press, Ado-Ekiti.

Oviawe, M.J.I. (2010), "Repositioning Nigerian youths for economic empowerment through entrepreneurship education”, European Journal of Educational Studies, Vol. 2 No. 2.

Penaluna, K., Penaluna, A. and Jones, C. (2011), "Towards an understanding of the global context of enterprise education", ISBE.

Rae, D. and Woodier-Harris, N. (2013), "How does enterprise and entrepreneurship education influence postgraduate students' career intentions in the New Era economy?", Educationp Training, Vol. 55 Nos 8/9, pp. 926-948.

Ratten, V. (2014), "Encouraging collaborative entrepreneurship in developing countries: the current challenges and a research agenda", Journal of Entrepreneurship in Emerging Economies, Vol. 6 No. 3, pp. 298-308.

Ripollés, M. and Blesa, A. (2005), "Personal networks as fosterers of entrepreneurial orientation in new ventures", The International Journal of Entrepreneurship and Innovation, Vol. 6 No. 4, pp. 239-248.

Robertson, M., Collins, A., Medeira, N. and Slater, J. (2003), "Barriers to start-up and their effect on aspirant entrepreneurs", Educationp Training, Vol. 45 No. 6, pp. 308-316.

Robeyns, I. (2000), "An unworkable idea or a promising alternative?: Sen's capability approach re- examined" Discussion Paper 00.3, Katholieke Universiteit Leuven, Centre for Economic Studies, available at: https://feb.kuleuven.be/drc/Economics/research/dps-papers/dpsoo/dpsoo3o.pdf (accessed 25 April 2016).

Robeyns, I. (2005), "The capability approach: a theoretical survey", Journal of Human Development, Vol. 6 No. 1, pp. 93-117.

Robinson, P.B. and Sexton, E.A. (1994), "The effect of education and experience on selfemployment success", Journal of Business Venturing, Vol. 9 No. 2, pp. 141-156.

Santos, J.R.A. (1999), "Cronbach's alpha: a tool for assessing the reliability of scales", Journal of Extension, Vol. 37No. 2, pp.1-5.

Sautet, F. (2013), "Local and systemic entrepreneurship: solving the puzzle of entrepreneurship and economic development", Entrepreneurship Theory and Practice, Vol. 37 No. 2, pp. 387-402. 
Sen, A.K. (1992), Inequality Re-Examined, Clarendon Press, Oxford.

Somsuk, N., Wonglimpiyarat, J. and Laosirihongthong, T. (2012), "Technology business incubators and industrial development: resource-based view", Industrial Management \& Data Systems, Vol. 112 No. 2, pp. 245-267.

Stanger, A.M.J. (2004), "Gender-comparative use of small business training and assistance: a literature review”, Educationp Training, Vol. 46 Nos 8/9, pp. 464-473.

Steenekamp, A.G., Van der Merwe, S.P. and Athayde, R. (2011), "An investigation into youth entrepreneurship in selected South African secondary schools: an exploratory study", Southern African Business Review, Vol. 15 No. 3, pp. 46-75.

Tope, A., Otaki, A.O. and Margret, B. (2014), "Entrepreneurship education: a panacea to graduate unemployment in Nigeria”, Journal of Sustainable Development in Africa, Vol.16 No.4.

Ukpong, J.S. (2013), "Curriculum redesign and entrepreneurship skills acquisition at tertiary education level", Journal of Education and Leadership Development, Vol. 5 No. 2.

Van Aardt, I., Van Aardt, C., Bezuidenhout, S. and Mumba, M. (2008), Entrepreneurship and New Venture Management, Oxford University Press, Southern Africa.

Varadjanin, V., Viduka, B. and Dimic, G. (2014), "An overview of entrepreneurship education in vocational high schools in Eu And Serbia", The 2nd International Conference on Research and Education - Challenges Toward the Future, Shkodra, 3031 May 2014.

Welter, F. and Kautonen, T. (2005), "Trust, social networks and enterprise development: exploring evidence from East and West Germany", The International Entrepreneurship and Management Journal, Vol. 1 No. 3, pp. 367-379.

Wharton, A.S. and Baron, I.N. (1987), "So happy together? The impact of gender segregation on men at work", American Sociological Review, Vol. 52 No. 5, pp. 574-587.

World Bank (2016), "Doing business 2017: equal opportunity for All", available at: www.doingbusiness.org/rv/media/WBG/DoingBusiness/Documents/AnnualReports/English/DB17-Report.pdf (accessed 25 April 2016).

\section{Further reading}

Kunene, T.R. (2008), "A critical analysis of entrepreneurial and business skills in SMEs in the textile and clothing industry in Johannesburg, South Africa", Unpublished manuscript, Doctoral dissertation, University of Pretoria, Pretoria.

\section{About the authors}

Kenechukwu Ikebuaku is a Social Science Researcher. He obtained MA in development studies at the Institute for Social Development, Faculty of Economic \& Management Science, University of the Western Cape (UWC), South Africa. Kenechukwu ikebuaku is the corresponding author and can be contacted at: keneike2005@yahoo.com

Mulugeta Dinbabo is a Senior Lecturer at the Institute for Social Development, Faculty of Economic \& Management Science, University of the Western Cape (UWC), South Africa. He obtained $\mathrm{PhD}$ in development studies from the University of the Western Cape, South Africa. 